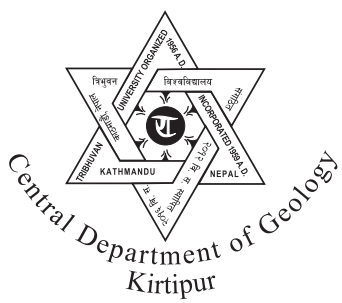

\title{
Stratigraphy and depositional environments of basin-fill sediments in southern Kathmandu Valley, Central Nepal
}

\author{
*Mukunda Raj Paudel ${ }^{1}$ and Harutaka Sakai ${ }^{2}$ \\ ${ }_{1}^{1}$ Department of Geology, Tribhuvan University, Tri-chandra Campus, Kathmandu, Nepal \\ ${ }^{2}$ Department of Geology and Mineralogy, Kyoto University, Kyoto 606-01, Japan
}

\begin{abstract}
Quatenary fluvio-lacustrine basin-fill sediments in the southern part of the Kathmandu Basin was studied in order to clearify the stratigraphy and reconstruct the sedimentary environment during the initial stage of the Paleo-Kathmandu Lake. Six stratigraphic units; Tarebhir, Lukundol, Itaiti, Kalimati, Sunakothi Formations and Terrace gravel deposits, have been described based on field observation of lithology and sediment distribution. The Tarebhir Formation is the basal unit which is overlained by alluvial fan of the Itaiti Formation in the southern part and by the marginal lacustrine deposit of the Lukundol Formation towards the northern part. Further $3 \mathrm{~km}$ toward the north from the basin margin at Jorkhu the the Lukundol Formation is overlain by the open lacustrine facies of the Kalimati Formation. At the same locality the latter is overlain by fluvio-lacustrine facies of the Sunakothi Formation. Moreover, the Terrace gravel deposits erosionally cover the Sunakothi Formation. The Kalimati Formation thickens northward, while the Sunakothi Formation thickens between the central and southern part of the basin. The study shows that the Sunakothi Formation is of fluvio-lacustrine (fluvial, deltaic and shallow lacustrine) origin and extends continuously from the southern margin $(\sim 1400 \mathrm{~m}$ amsl $)$ to the central part $(\sim 1300 \mathrm{~m}$ amsl) of the basin. It also indicates that sediments of this formation were deposited at the time of lake level rise and fall. Thick gravel sequence in the southern margin represents the alluvial fan before the origin (before $1 \mathrm{Ma}$ ) of the Paleo-Kathmandu Lake, while thick gravel sequence situated above the Sunakothi Formation is the Terrace gravel deposits of the late Pleistocene age (14C method), deposited during and after the shrinkage of the Paleo-Kathmandu Lake from south to north.
\end{abstract}

\section{INTRODUCTION}

Kathmandu Valley is located in the Lesser Himalaya, and was an ancient lake named as PaleoKathmandu Lake till 11 kyr B.P. (Sakai et al. 2001). This basin is filled with very thick (up to 550m thick) sequence of lacustrine and fluvial deposits of PlioPleistocene age (Yoshida and Igarashi 1984, Moribayashi and Mauro 1980). First, significant works have been carried out by Yoshida and Igarashi (1984), Yoshida and Gautam (1988), Dongol

*Corresponding author:

E-mail address: mukunda10@ hotmail.com
(1985,1987), Sah et al. (1995), and Sakai (2001). Yoshida and Igarashi (1984) first established lithostratigraphic unit; the Lukundol Formation, which was the older lake sediments covered by three fluvial terraces i.e. the Chapagaon, Boregaon and Pyangaon. According to them, lake became narrow and shifted toward the north due to upheaval of the Mahabharat range. They proposed the units such as the Gokarna, Thimi and Patan formations, which belonged to their younger stage deposits. T. Sakai et al. (2001) reported that these formations belonged to the fluvio-deltaic deposits. Sah et al.(1995) proposed six stratigraphic units for the whole basin-fill sediments, i.e. Tarebhir, Lukundol, Sunakothi, Tokha, Kalimati and Thimi 


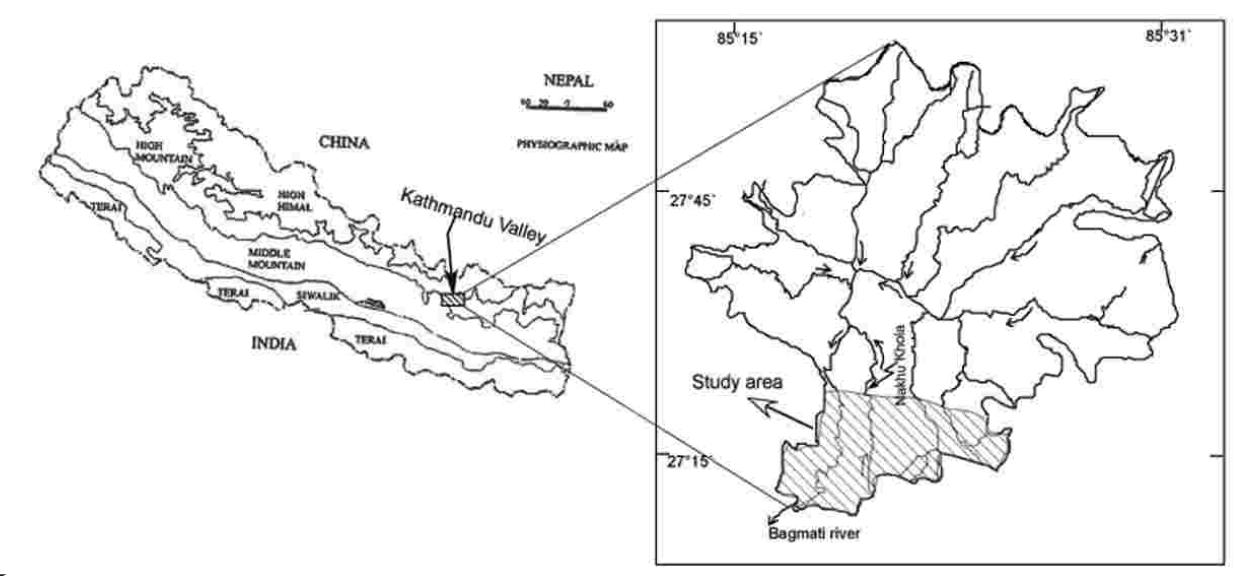

Fig. 1 Locauton map oı tne stucy area

formations. Sakai (2001) proposed different stratigraphic units in the south, central and northern part of the basin. Paudel (2004), Paudel and Sakai (2004 and 2006) explored lithological variation found from south to north of the basin on the basis of geological mapping including texture and composition of the sediments. The redefinded stratigraphic names are the Tarebhir, Lukundol, Itaiti, Kalimati, Sunakothi formations and Terrace gravel deposits in ascending order.

On the other hand, southernmost part of the basin, where oldest basin-fill sediments overlie the basement rock with an angular unconformity, is the important source of information regarding the history of the early stage of the Paleo-Kathmandu Lake. Moreover, in shallow and marginal lacustrine environments, relatively small change in lake level can influence on the depositional condition. In such areas, several lithological changes can take place (Bustillo et al. 2002). In this paper, we mainly focused on distribution of lithostratigraphic units in the southern marginal part (Fig.1), their correlation with the previously defined stratigraphic units, and their depositional environments.

\section{LITHOSTRATIGRAPHY}

The basin-fill sediments are broadly divided into three sedimentary facies: the fluvio-deltaic facies from north to center, fluvio-lacustrine facies from south to center, and garavelly fan and fluvial facies from southern margin of the basin (Sakai 2001). Dongol (1985 and 1987) classified the valley-fill sediments into older Lukundol Formation and younger Kalimati Clay. Further, the Lukundol Formation was divided into four members: the Tarebhir basal gravel member, Kaseri-Nayankhandi lignite, Nakhu Khola mudstone, and Champi-Itahari gravel in ascending order. Gravel of the Tarebhir Formation was interpreted to be originated from southern rim of the basin. This gravel sequence represents fan deposits, which are spreading from south to northand is covered by $6 \mathrm{~m}$ thick conglomerate with pebbly sandstone and cross-bedded sand. Clast consists of gneiss and mica schist, originated from the Shivapuri Gneiss to the north. The present field study indicates that the whole sequence of the Tarebhir Formation is not alluvial fan deposits from south.

Yoshida and Igarashi (1984) proposed three different terraces above the Lukundol Formation. Similarly, Shrestha et al. (1999) showed the Chapagaon Formation along the Nakhu Khola area. Sawamura (2001) showed the Kalimati Formation as the lateral facies change of the Itaiti and the Lukundol formations. Therefore, different authors have proposed differently the stratigraphic units of the southern part of the basin. With geological mapping, texture and composition of the sediments, we conclude that Lukundol Formation is the fluvial and marginal swamp facies, which is different from the lacustrine facies of the Kalimati Formation that extends upto the southern part of the basin, and changes into the fluvio-lacustrine facies of the Sunakothi Formation, and is also covered by the Terrace gravel deposits.

The Itaiti Formation is restricted only in the 


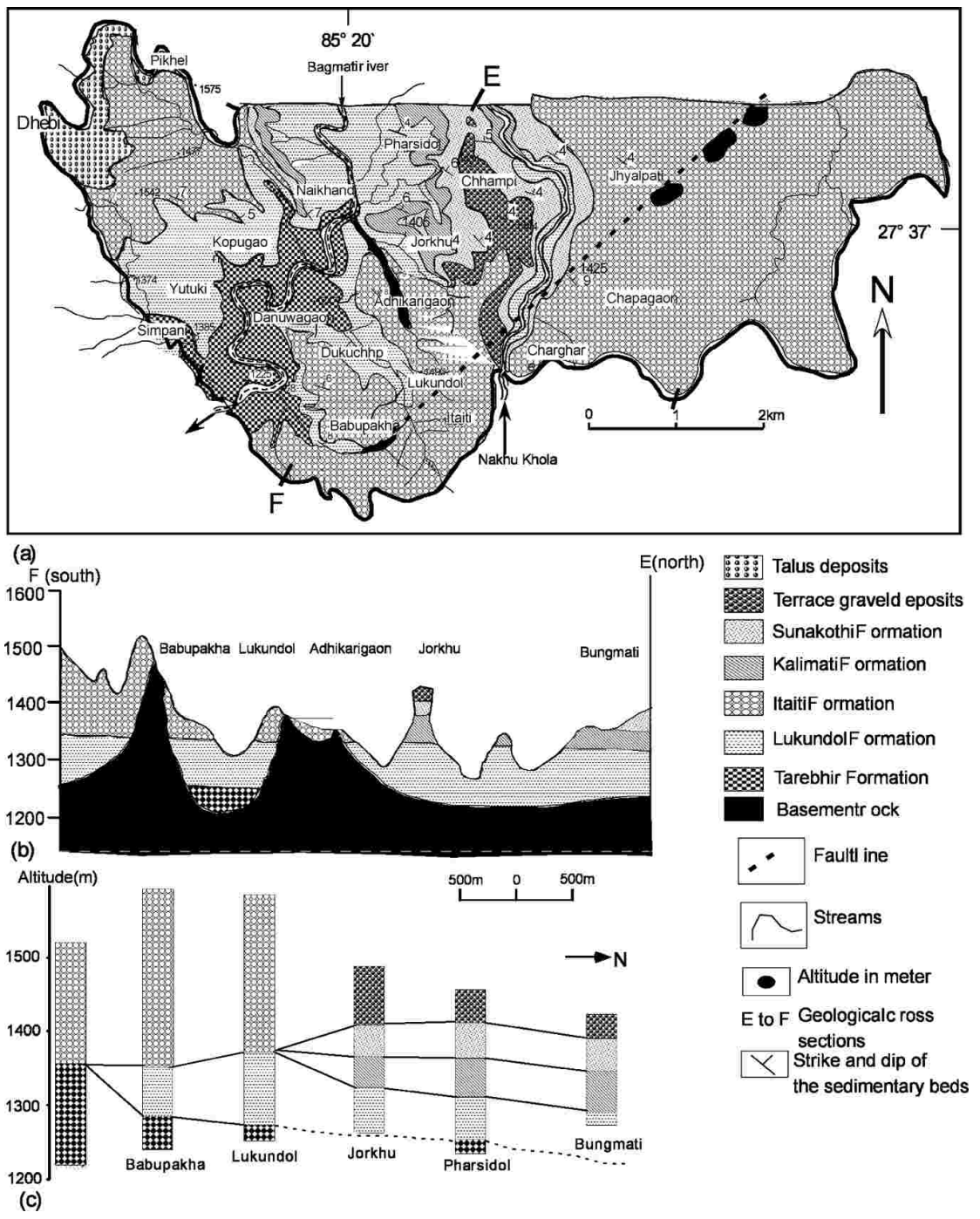

Fig. 2 (a) Geological map of the southern part of the Kathmandu Basin (b) Geological cross-section along south to north. (c) Lithostratigraphic changes from southern margin to the central part of the basin

southern margin of the basin and shows alluvial fan. Northwards from the southern margin are thick gravel deposits covering the Sunakothi Formation and is the terrace gravel deposits in this study (Fig. 2). The Kalimati Formation is not a lateral facies change of the Itaiti and Lukundol formations (Sawamura 2001). The Chapagaon Formation mentationed by Shrestha et al. (1999) does not cover the Lukundol Formation along the whole Nakhu Khola area. A detailed lithostratigraphy and their distribution from south to central part of the basin is given, and the following stratigraphic units; Tarebhir, Lukundol, Itaiti, Kalimati,
Sunakothi formations and terrace gravel deposits, are described from bottom to top.

\section{Tarebhir Formation}

The Tarebhir Formation is well exposed in the Tarebhir and Danuwargaon areas, at the southern margin of the valley. The succession is about $120 \mathrm{~m}$ thick and is entirely composed of conglomerates and intercalated sand and mud (Fig. 3 and 4). The conglomerate beds mostly consist of pebble, cobble and boulder of quartzite, slate, phyllite, granite and limestone. The clasts are mainly rounded to sub- 
Fig. .3 Detailed columnar section of the Tarebhir Formation at the type loality Tarebhir in the southern margin of the basin. Deatailed paleocurrent direction and composition of the clasts from bottom to top are shown on the left diagrams

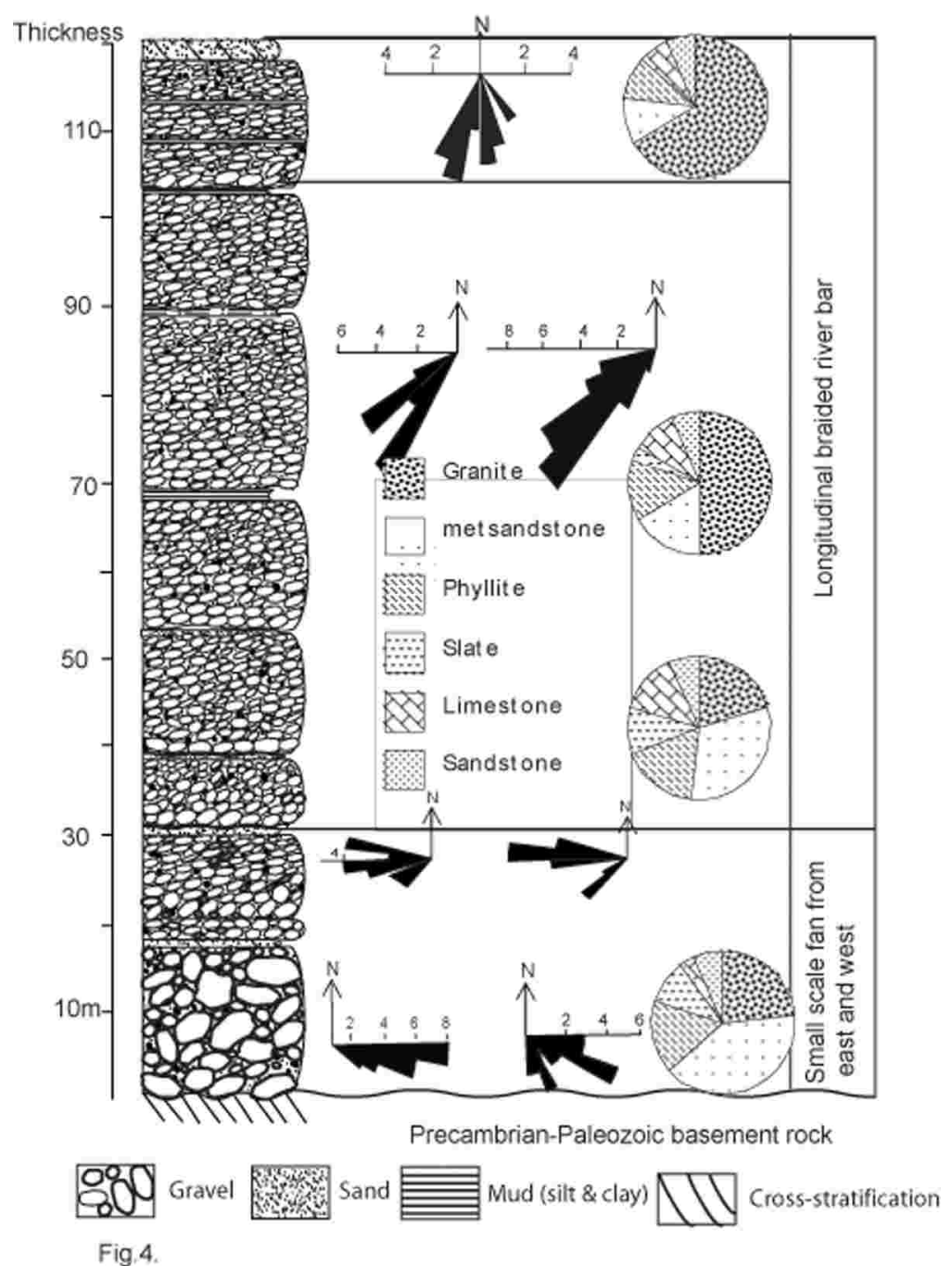

and granite (Fig. 5). Conglomerates are roughly horizontal, and the sequence is about $30 \mathrm{~m}$ thick. The basal part is distributed in Katuwaldaha, southern end of the basin, and rests on the basement rocks of the Kathmandu Valley (Fig. 6).

\section{Middle part}

The middle part of the Tarebhir Formation consists of rounded to subrounded pebble and cobble of tourmaline granite, metasandstone and phyllite. Content of granite pebbles and their roundness increase towards younger successions. More than $60 \%$ of the clasts in this part is made up of tourmaline granite. Sand and mud beds of $200600 \mathrm{~mm}$ thickness are interbedded within thick gravel beds. The conglomerate beds show planar and horizontal stratification with imbrication of gravel. Thickness 


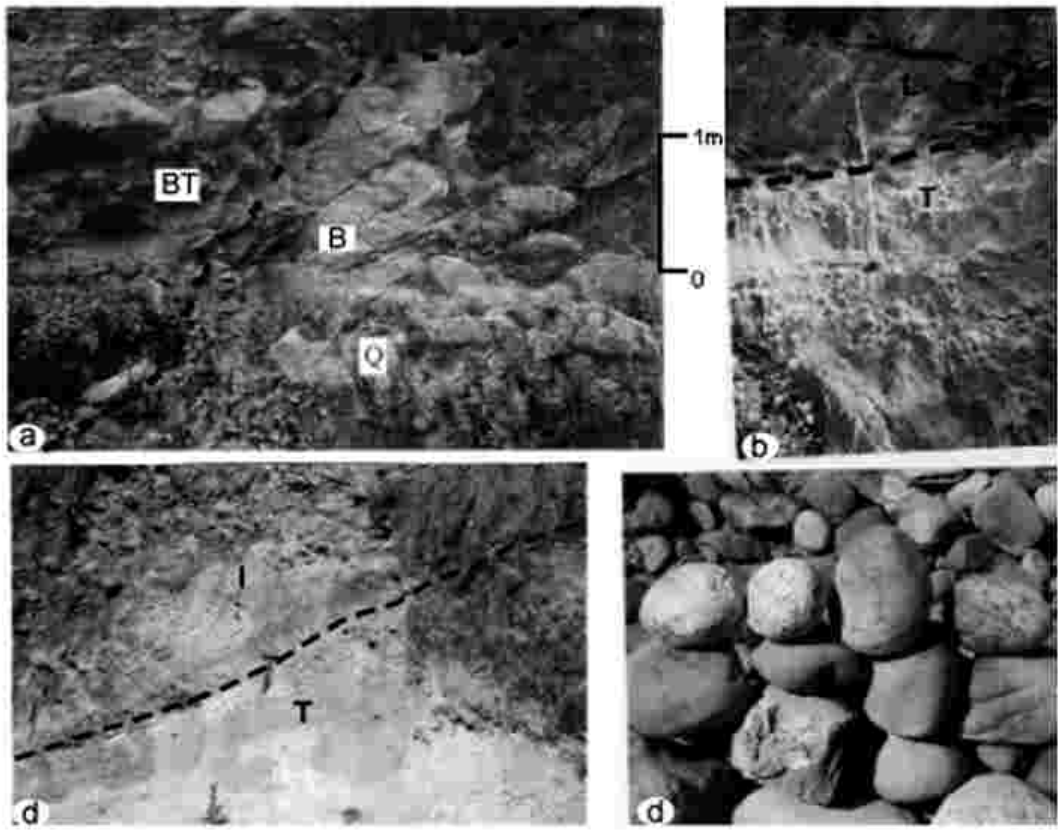

Fig. 4 Photographs of the Tarebhir Formation: (a) Oldest basin-fill sediments unconformably overlain on the Precambriam basement rocks of the Kathmandu Valley. Q: Quarzose sandstone, BT: basal part of the Tarebhir Formation (b) Gravelly Tarebir Formation (T) is overlain by fluvial swamp of Lukundol Formation (L), (c) Gravelly Tarebhir Formation (T) is directly overlain by alluvial fan of the Itaiti Formation (I); (d) Composition of the clast of the Tarebhir Formation at the middle part of the middle part is about $60 \mathrm{~m}$. Difference between the basal part proposed by Dongol (1985) and the middle part of this study lies on composition of the clasts.

\section{Upper part}

The upper part of the Tarebhir Formation is composed of the pebbly gravel, micaceous crossbedded pebbly sand and mud beds. Increasing proportion of sand and mud beds are the characteristic features of this subunit. Beds are more or less horizontal with imbrication of gravel. This subunit is about $30 \mathrm{~m}$ thick. The uppermost part of the Tarebhir Formation is directly overlained by the metasandstone gravel sequence of the Itaiti Formation (Fig. 6) in the southern margin, and by the muddy sequence of the Lukundol Formation toward the center of the basin (Fig. 6).

\section{Lukundol Formation}

Dhaundial (1966) first proposed the name of this formation. Dongol (1985) considered the lower part as the Kaseri-Naikhandi Lignite or lignite member of the Lukundol Formation, the middle part as the Nakhu Khola mudstone or silt member of the Lukundol Formation, and the upper part as the Champi-Itahari gravel of the upper gravel member of the Lukundol Formation. Sakai (2001) considered the Lukundol Formation of the present study, as the middle part of the Lukundol Formation, and modified the stratigraphic division in this area and gave the name the Lukundol Formation to the southern part of the basin. The formation conformably overlies the Tarebhir Formation (near Danuwargaon) and is about $92 \mathrm{~m}$ thick, distributed in Lukundol, Naikhandi and Khahare (Fig. 2a). Repetition of the sand, silt, mud lignite and carbonaceous mud are the main lithology of this formation (Fig. 5). Dongol (1985) and Sah et al. (1995) reported vertebrate and invertebrate fossils from this formation. Such type of sequence can be observed along the both banks of the Bagmati River and its tributaries in Lukundol, Naikhandi and upstream of the Nakhu Khola (Fig. 2a). On the basis of the lithology, the Lukundol Formation is divided into lower, middle and upper parts.

\section{Lower part}

The lower part of the Lukundol Formation is exposed extensively along the Bagmati River, Khahare and Dukuchhap. The thickness of this subunit is 27 $\mathrm{m}$ and is mainly composed of thick, cross-bedded, coarse pebbly micaceous sand, bioturbeted silty sand, silt, carbonaceous clay and lignite (Fig. 5). Dominant lithology of this subunit is sand. Koirala et al. (1993) and Sakai (2001) reported diamictites from this formation. The most characteristic feature of this subunit is alteration of the sand and carbonaceous 


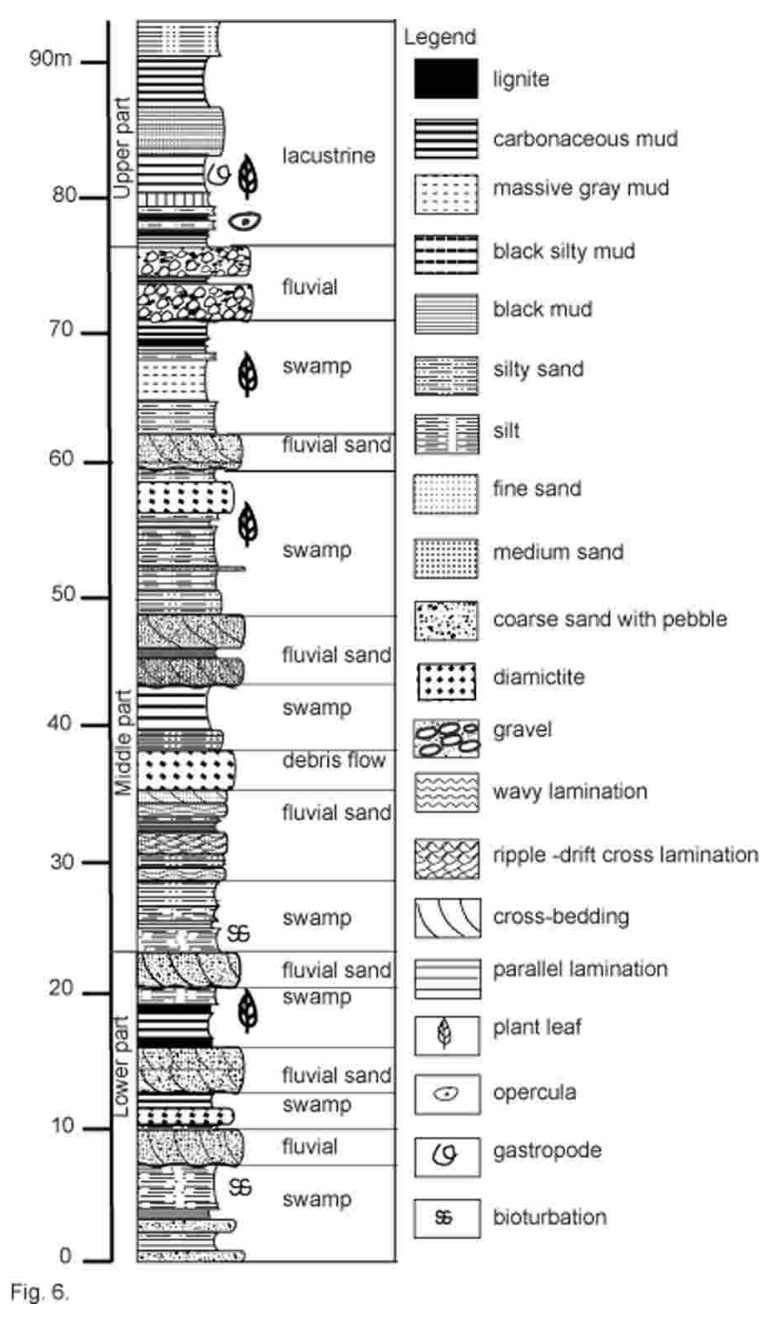

Fig. 5 Lithostratigraphy of the Lukundol Formation at the Lukundol area. On the basis of different lithology it is divided into lower to upper part

mud beds.

\section{Middle part}

The middle part is composed of fine silty sand, fine sand with black mud and lignite. The succession contains wavy cross-laminated and ripple-drift crosslaminated sand and coarse cross-bedded sand. The topmost part of the subunit consists of thick lenticular gravel beds. This subunit contains invertebrate and vertebrate fossils as well as the plant leaves. The main features are the small-scale sedimentary structure (Fig. 5) and the lesser proportion of the coarse sand than the lower part of the Lukundol Formation. The thickness of this subunit is about $49 \mathrm{~m}$.

\section{Upper part}

The upper part of the Lukundol Formation consists of fine-laminated silty sand, fine sand, carbonaceous mud, lignite and diatomaceous bed. The characteristic features of this subunit are thick bed of thinly laminated silty sand, and laminated carbonaceous mud with plant leaves, mollusca and opercula (Fig. 5). Thickness of this subunit is $16 \mathrm{~m}$ at Lukundol.

\section{Itaiti Formation}

This stratigraphic unit is only distributed in the southern marginal part of the Kathmandu Valley. It is comprised of thick bed of pebble-cobble conglomerate, sand and mud. The gravel is composed mainly of metasandstone, phyllite, and quartzite. The maximum thickness of this formation is $190 \mathrm{~m}$ and is mostly distributed in the elevated area. The name of this formation was first proposed by Sakai (2001). Sah et al. (1995) included this sequence within the Lukundol Formation. Yoshida and Igarashi (1984) explained this sequence within the Terrace gravel deposits, while Dongol (1985) introduced the name Champi-Itaiti gravel. Paudel (2004) suggested that this sequence did not only cover the Lukundol Formation but also covered the Tarebhir Formation in the southern margin, and the Sunakothi Formation toward the center, and suggested to separate this gravelly sequence laterally into different units from the southern margin and toward the basin center. From the present study, this formation is redifined for the unit distributed only in the southern marginal part of the basin. Furthermore, this formation is divided into the distal and proximal part (Fig.6) based on gravel size and interbedding of the sand and mud beds.

In the southern margin of the study area, the Itaiti Formation consists of thick gravel beds with interbedded sand and mud. Towards north from the basin margin, thickness of this formation gradually decreases. The thickest part is distributed around Babupakha, which is about $190 \mathrm{~m}$ resting on the basement rock of the Kathmandu Complex. The lower part consists of large disorganized conglomerate. Maximum size of gravel is about $0.8 \mathrm{~m}$ and with wide size range and poor sorting, as is observed at 


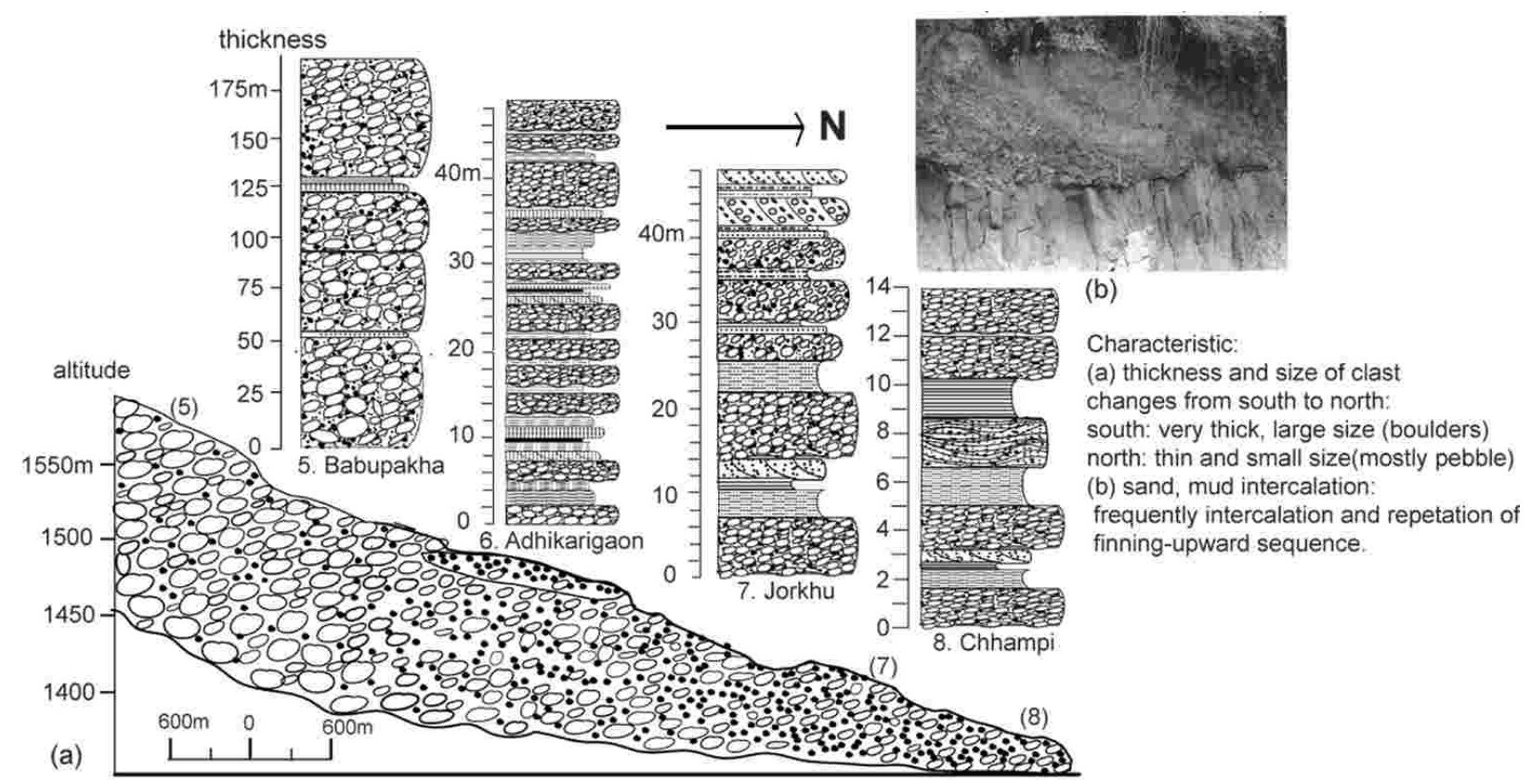

Fig. 6 (a) Lithofacies changes within the Itaiti Formation from proximal to distal part (b) Photograph showing cross-bedded fluvial gravel above the upper part of the Sunakothi Formation

Babupakha. Sand and mud beds are occasionally interbedded in between the conglomeratic sequences. Beds are generally horizontal. The formation exhibits unconformable contact with the basement rock in Babupakha, and with the Lukundol Formation in Dukuchhap and Pharping. In Katuwaldaha (southern marging of the basin), the Itaiti Formation directly overlies the Tarebhir Formation.

\section{Kalimati Formation}

The Kalimati Formation consists of massive to very thin-laminated black and grey silt and mud, parallel laminated very fine sand and diatomaceous mud. Mud beds contain plant leaves, mollusca shells, and opercula. Along the Nakhu Khola, the sequence contains plant leaves and fish teeth. Beds are horizontal in the center but are inclined 4 to $11^{\circ} \mathrm{N}$ in the southern part. The same lithological sequence is found in the center part of the basin. Dhoundial (1966) first described this unit as the Kalimati Formation.
Dongol (1985 and 1987) considered as the Kalimati Clay. Yoshida and Igarashi (1984) described it as Patan Formation. Sah et al (1995) used the Kalimati Formation for narrowly distributed clay within the central part of the basin. Sakai (2001) mentioned thick bed of the Kalimati Formation in the central part of the Kathmandu Basin, which extends thinly toward the southern part. The exposed thickness of the formation in the southern part is $40 \mathrm{~m}$. Boundary between the overlying Sunakothi and the underlying Kalimati formations in the southern part at Jorkhu can be observed at the altitude 1365 amsl, while from this location toward the center near the Manohara River, the boundary between Sunakothi and Kalimati formations exists at about $1300 \mathrm{~m}$ amsl. The horizontal distance between these two locations is $5.5 \mathrm{~km}$. From Jorkhu to $2 \mathrm{~km}$ towards north, the boundary between these two formations is located at the Nakhu Khola, where the beds $\operatorname{dip} 11^{\circ} \mathrm{N}$. 


\section{Sunakothi Formation}

The type locality of the Sunakothi Formation is designated at Sunakothi $3.0 \mathrm{~km}$ south from the Patan (Paudel and Sakai 2005 and 2006). The name of this unit is first proposed by Sah et al (1995). Sakai (2001) suggested that it is a southern extension of the Thimi Formation. Paudel (2004) and Paudel and Sakai (2004 and 2005) suggested that it is a different stratigraphic unit than the Thimi and Lukundol formations. The formation is composed of the alternating beds of mud and sand at the basal part in the southern margin. The formation is sandy, muddy and gravelly at the middle part, and is sandy to silty at the upper part. Parallel and climbing ripple laminations are developed in fine sand. The outcrop is well exposed in Sunakothi, along the Kyakudol Khola between Jorkhu and Parigaon. The exposed thickness of this formation is about 34 to $60 \mathrm{~m}$, and is distributed from $1420 \mathrm{~m}$ amsl in the southern margin to nearly $1300 \mathrm{~m}$ amsl at central part of the basin. The formation is underlain by the Kalimati Formation and is overlain by the Terrace gravel deposits. The boundary between the Kalimati and Sunakothi formations is gradational to erosional.

\section{Terrace gravel deposits}

This unit is mainly composed of pebble-cobble gravel. The organization of the clast is well showing the layer of different sized gravel, and also interbedded sand and mud beds. Horizontal layers show good imbrication and also cross-bedded gravels and sand are prominent (Fig. 6c). This conglomerate sequence is often interbedded with very thin carbonaceous mud and sand. Both fining and coarsening-upward sequence is clearly observed within the outcrop. Planar cross-bedded gravels show imbrication. In some locality the conglomerate shows strong scouring in the silty clay of the Sunakothi Formation. This stratigraphic unit is well exposed in Chhampi and Chapagaon Sunakothi and Thecho. At the central part of the basin, a thick terrace gravel with metasandstone and quartzite clasts erosionally covers the Sunakothi and Kalimati formations.

One remarkable point about thick gravelly sequence is, its contact relation between the different formations. Previously whole gravel sequence was considered as the alluvial fan by Sakai (2001). This gravelly sequence overlie the Tarebhir, Lukundol and
Sunakothi formations from proximal to the distal parts. The proximal part of the gravel is interpreted as alluvial fan of the Itaiti Formation while toward the basin center is the Terrace gravel deposits.

\section{DISTRIBUTION AND CHANGES OF STRATIGRAPHIC UNITS}

In the southern marginal part of the basin, older basin-fill sediments of the Tarebhir Formation is directly overlain by the fan of the Itaiti Formation. Imbrication of pebbles and composition of the detritus of the Tarebhir and Itaiti formations indicate that the source of the sediments changed at the time of deposition of these stratigraphic units. Detritus of the Tarebhir Formation were mostly from north and small-scale sedimentation occurred from east and west at the basal part. Detritus of the Itaiti Formation were mostly from south and southeast (Fig. 6b).

Toward the north from the basin margin at Danuwarganon marginal lacustrine facies of the Lukundol Formation is located between the alluvial fan and fluvial facies of the Itaiti and Tarebhir formations. Composition of the detritus of the Lukundol Formation showed that the main source was from north. However, around the periphery of the basement rock, detritus was perhaps transported from east, west and south.

About $3.0 \mathrm{~km}$ north from the basin margin, open lacuastrine facies of the Kalimati Formation overlie the marginal lacustrine facies of the Lukundol Formation (Paudel 2004; Paudel and Sakai 2004). Again, this open lacustrine facies of the Kalimati Formation is covered by the fluvio-lacustrine facies of the Sunakothi Formation. This Sunakothi Formation from the Jorkhu ( $\sim 3 \mathrm{~km}$ north from the basin margin) is erosionally covered by the $2 \mathrm{~m}$ to more than $25 \mathrm{~m}$ thick terrace gravels. This sequence is continuing from the south to the central part of the basin. Paleocurrent and compositional data of the Sunakothi sediments show southern sources.

\section{DEPOSITIONAL ENVIRONMENTS}

Four facies in the southern part of the Kathmandu Basin are (a) fluvial facies of the Tarebhir and the lower part of the Lukndol formation, (b) fluvialswamp facies of the middle and upper part of the 


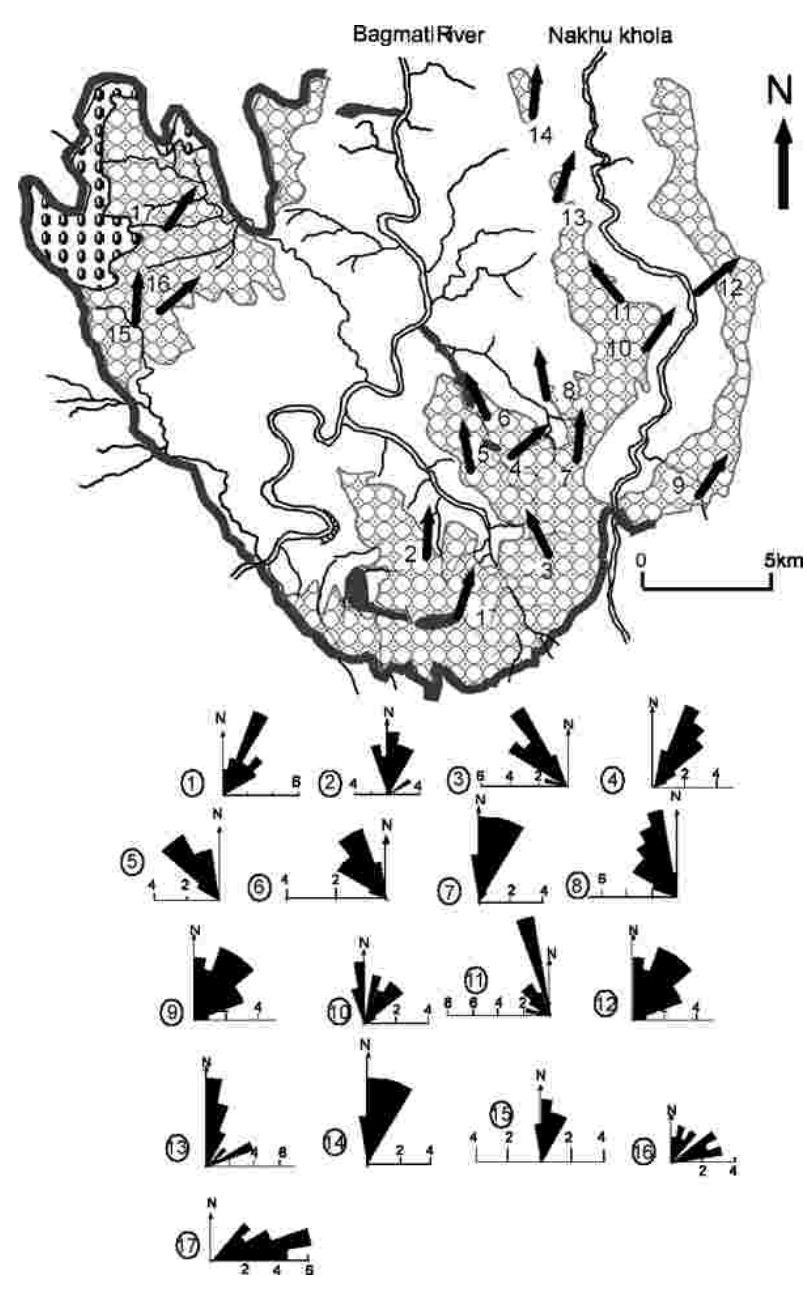

Fig. 7 Paleocurrent direction of the gravel sequence (Fan and Terrace gravel) in the southern part of the Kathmandu Basin. Arrow inside the map is the average paleocurrent direction of the pebbles. Total numbers of the Imbrication of the pebbles is shown in the rose diagrams

Lukundol Formation, (c) lacustrine facies of the Kalimati Formation and lakeshore or fluvio-lacustrine facies of the Sunakothi Formation, and (d) alluvial fan facies of the Itaiti Formation.

Fluvial-swamp facies of the Lukundol Formation shows the repetation of the fluvial and swamp facies before the lacustrine facies was formed in the southern basin margin. The Kalimati Formation shows the open lacustrine facies whereas the Sunakothi Formation shows the fluvio-lacustrine facies, which is gradually changing into the fluvial facies. Alluvial fan facies of the Itaiti Formation itself is divisible into proximal alluvial fan facies lying in the south, and distal braided river facies lying towards the north.

Vertically they changed from fluvial facies to fluvial-swamp facies and to lacustrine facies, and from lacustine to gravelly fluvial facies. The gravelly braided river changed onto the alluvial fan (Fig. 2c). To the north, the braided river changed onto the fluvial swamp (Lukundol Formation). The fluvialswamp extended $3.5 \mathrm{~km}$ to the north from the basin margin to the open lacustrine Kalimati Formation, and vertically changed into the fluvio-lacustrine Sunakothi Formation. The fluvio-lacustrine facies covered the gravelly fluvial facies is pinching towards the south, while the open lacustrine facies of the Kalimati Formation is gradually thickening toward the north.

Extensive poorly drained swamp depositional environment of the Lukundol Formation in the southern part laterally changed into the well-drain swamp towards the center (Bunmati-Khupi). In this area no small lacustrine condition prevailed. Fluvial system of the Lukundol Formation directly changed into open lacustrine system of the Kalimati Formation.

Composition of the detritus of the Lukundol Formation showed that the main source was from north. However, around the periphery of the basement rock, detritus was perhaps transported from east, west and south. Paleocurrent and compositional data of the Sunakothi sediments show southern sources.

\section{CONCLUSIONS}

On the basis of mapable distinct lithology, stratigraphy of the Kathmandu basin-fill sediments are redefined as the Tarebhir, Lukundol, Itaiti, Kalimati, Sunakothi Formations and Terrace gravel deposits. Among these units Itaiti Formation is restricted in the southern marginal part of the basin, and the rest on the Precambrian basement and the Lukundol Formation, except the terrace gravel deposits that erosionally covered the fluvio-lacustrine of the Sunakothi Formation from south to the central part of the basin. This terrace gravel was deposited during and after the ancient Paleo-Kathmandu Lake while gravel sequence of the Itaiti Formation was deposited before the origin of the proper Paleo-Kathmandu Lake. Redefined Sunakothi Formation and the Terrace gravel deposits were continuously extended from the 
south to the central part of the basin, and were deposited during the last stage of the Paleo-Kathmandu Lake. All the detritus of these two units were transported from the south of the Kathmandu Valley.

\section{ACKNOWLEDGEMENT}

The first author carried out this research as a part of the M. Sc. course in the framework of MONBUSHO in Kyushu University. We would like to thank Hiroshi Nisi (Hokkaido University), and Yoshihiro Kuwahara, Masao Ohno and Kiyotaki Ishida (Kyushu University) for various cooperation. We are grateful to Prof. B. N. Upreti, Dean Institute of Science and Technology for providing suggestion. We are thankful to the Director General and staff of the Department of mines and Geology, Nepal for cooperation to bring the samples to Kyushu University. We also thank Satoshi Funakawa (Former JOCV in Tribhuvan University, Nepal) for his help and support.

\section{REFERENCES}

Bustillo, M. M., Arribas. M. A., and Bustillo, M., 2002. Dolomitization and silicification in low energy lacustrine carbonate (Paleogenne, Madrid Basin, Spain), Sedimentary Geology v. 151, pp. 107126.

Dongol, G.M.S., 1985. Geology of the Kathmandu fluviolacustrine sediments in the light of new vertebrate fossils occurrences. Jour. Nepal Geol. Soc, v. 3, pp. 4347.

Dongol, G.M.S., 1987. The stratigraphic significance of vertebrate fossils from the Quaternary deposits of the Kathmandu Basin, Nepal. Newsl. Stratigraphy, v.18, no.1, pp. 2129.

Dhoundial, E. P., 1966. Investigation of lignite deposits in the Kathmandu Valley, Nepal. Unpub. G.S.I. report, 3p.

Koirala, A., Shrestha, O. M., and Karmacharya, R., 1993. Engineering geology of the southern part of the Kathmandu Valley. Jour. Nepal Geol. Soc., v.3 (Sp. Issue), pp. 151159.

Moribayashi, S. and Maruo, Y., 1980. Basement topography of the Kathmandu Valley, Nepal-an application of the gravitational method to the survey of a tectonic basin in the Himalaya. Jour. Japan Soc. Engn. Geol., v. 21, pp.30 37.
Paudel, M. R., 2004. Depositional environmental changes in the southern part of the Kathmandu Valley, Central Nepal, M. S. dissertation submitted to Kyushu University, Ropponmatsu Campus, Japan, 135p.

Paudel, M. R., and Sakai, H., 2004. Stratigraphy and depositional environment of the basin-fill sediments in the southern part of the Kathmandu Valley, central Nepal, Abstract, the 111 Annual meeting of the Geological Society of Japan, 308p.

Paudel, M.R. and Sakai, H., 2005. Depositional environment and Stratigraphic position of the Sunakothi Formation, in the southern part of the Kathmandu Valley, Central Nepal. The 112th annual meeting of the Geol. Soc. Japan, Kyoto, Japan, 39p.

Paudel, M.R, and Sakai, H., 2006. Late Pleistocene depositional environmental changes in the draining stage of the Paleo-Kathmandu Lake in the southern part of the Kathmandu Basin, Central Nepal, ISC Fukuoka 2006, pp.127 127.

Sawamura, F., 2001. Sedimentary facies changes recorded in the Plio-Pleistocene Kathmandu Basin Group in the southern part of the Kathmandu valley, Nepal. Jour. Nepal Geol. Soc., v.25 (Sp.Issue), pp.33 42.

Sakai, T., Gajurel, A.P., Tabata, H., and Upreti B.N., 2001. Small amplitude lake level fluctuations recorded in aggrading delta deposits of the upper Pleistocene Thimi and Gokarna formations, Kathmandu Valley, Nepal. Jour. Nepal Geol. Soc., v 25 (Sp. Issue), pp. 4351.

Sakai, H., 2001. Stratigraphic division and sedimentary facies of the Kathmandu Basin sediments. Jour. Nepal Geol. Soc., v. 25 (Sp. Issue), pp.19 32.

Sah, R.B., Paudel, M., and Ghimire, D, 1995. Lithological succession and some vertebrate fossils from the fluviolacustrine sediments of Kathmandu Valley, Central Nepal. NAHSON, v. 5, no. 6, pp. 2127.

Shrestha, O.M., Koirala, A., Karmacharya, S.L., Pradhananga, U.B., Pradhan, R., and Karmacharya, R., 1999. Engineering and environmental geological map of the Kathmandu Valley (1:50,000). Dept. Mines and Geology, HMG Nepal.

Yoshida, M and Igarashi, Y., 1984. Neogene to Quaternary laustrine sediments in the Kathmandu Valley, Nepal. Jour. Nepal Geol., Soc., v. 4 (Sp. Issue), pp. 73100.

Yoshida, M. and P. Gautam, 1988. Magnetostratigraphy of Plio-Pleistocene lacustrine deposits in the Kathmandu Valley, central Nepal. Proc. Indian national, science academy, v. 54A, no. 3, pp. 410417. 